\title{
Implementation of Rice and Maize Cultivation Technology Based on Agronomic Effectiveness
}

\author{
Yustisia ${ }^{1, *}$, Damasus Riyanto ${ }^{2}$, Tumarlan Thamrin ${ }^{1}$ and Johanes Amirrullah ${ }^{1}$ \\ ${ }^{1}$ South Sumatra Assesment Institute for Agricultural Technology, Kol. H. Burlian Km.6 No. 83 \\ Palembang Sumatera Selatan \\ ${ }^{2}$ Yogyakarta Assesment Institute for Agricultural Technology, Karangsari-Sleman, Yogyakarta
}

\begin{abstract}
The existing land characteristics and inappropriate management during intensive agricultural practice on upland, swampland, and paddy field are the factors that causing land productivity to be low and decreasing. Alternative efforts to increase the land, rice, and maize productivities could be carried out through the implementation of SiteSpecific Nutrient Management technology based on the RAE parameter. This paper presents thoughts on the opportunities for refocusing RAEbased research on agricultural cultivation technology, and research results that have been done.The research of rice and maize with RAE in the upland and paddy field has resulted in a location-specific cultivation technology package. The technologies that have been produced are single NPK inorganic fertilizer package, the combination of single NPKcompound NPK inorganic fertilizers, the combination of single NPK inorganic fertilizer-organic fertilizer, and combination of single NPK inorganic fertilizer-biofertilizer. By using RAE value, these researches have shown a more effective technology package in comparison with standard technology. The technology devices for determining standard fertilization needed to support the research with RAE parameter as the basis are available. The said devices are Upland, Swampland, and Paddy Soil Test Kit. Refocusing research of location-specific fertilization that explicitly using RAE parameter is relevant to promote sustainable agriculture.
\end{abstract}

\section{Introduction}

Drylands, swamplands, and non-swamp wetlands are the main lands that support agricultural development in Indonesia. The total area of these land resources reaches 188.038 million ha [1]. The implementation of various cultivation technology innovations on these lands has contributed to the increase in land productivity and crop production. However, to support sustainable agriculture, efforts to overcome the obstacles faced are still needed. The obstacles in drylands and swamplands are low land productivity due to biophysical, chemical, and biological constraints, while in non-swamp wetlands, a decrease in land productivity (degradation) due to inappropriate management. The area of paddy

\footnotetext{
*Corresponding author: yustisiasumsel1111@gmail.com
} 
fields in eight rice production centers in Indonesia reaches 4.69 million ha but $95.55 \%$ of it has been degraded [2].

Degraded rice fields, dry lands, and swamplands are classified as suboptimal lands. The characteristic parameters include, low P, K, C nutrient status, and low soil pH. Suboptimal land resources can still be improved such as through the implementation of the right fertilization technology.

The research on rice and Maize in the last decade has produced a fertilizer technology package. These technologies include: (a) a single NPK inorganic fertilizer, (b) a combination of single and compound NPK inorganic fertilizers, (c) a combination of a single NPK inorganic fertilizer with organic fertilizers, and (d) a combination of a single NPK inorganic fertilizer with biofertilizer. However, some of the technologies produced still use high input and has/has not oriented towards agronomic effectiveness

The diversity of resources, climate, and varieties requires fertilizer technology to be implemented according to location specification. Its implementation takes into account the status of soil nutrients and plant nutrient requirements [3, 4]. Zaini cit. Zaini 2012 [5] mention that, fertilization of location specification has been introduced through the Integrated Rice Production Development program in 2002-2003. In the program, the fertilization of location specifications is one of the components of Integrated Plant Management technology. This technology component provides the largest portion of increase in grain yield and income of rice farmers. However, farmers have not implemented as recommended so that its development on a large scale is still slow.

An increase of adoption opportunities of fertilization technology for location specification can be implemented through reorientation of agronomic effectiveness-based research. Supports for the implementation of this effort are available such as the Nutrient Manager for Rice software or Site Spesific Nutrient Management/SSNM [5, 6]. At the farmer level, fertilization of location specification is determined using Upland Soil Test Kit, Swampland Soil Test Kit or Paddy Soil Test Kit.

Fertilization technology of specific alternatives is based on the dosage and/or combination of alternative fertilizer rates (inorganic, organic, and biological). This can be adjusted to the farmer's existing technology and the availability of onsite resources. Several research results showed that there was still a chance to increase the effectiveness of farming and the income of farmers in various specific locations. These opportunities can be identified through a parameter-based approach to relative agronomic effectiveness (RAE).

RAE parameter information in cultivation technology research has the opportunity to be an indicator that determines the adoption of a technology by farmers and will greatly determine the sustainability of its implementation. This paper presents thoughts on the opportunities for refocusing agronomic effectiveness-based research on agricultural cultivation technology, research results that have been done, and suggestions for follow-up. The availability of technology tools for determining standard fertilizers for location specification and enhancing the dissemination of information on the results of RAE-based research are expected to provide opportunities for increased adoption and sustainability of its implementation at the farm level.

\section{Sources of Rice and Maize Production, Constraints, and Potency of Utilization}

The diversity of growth and crop yields is largely determined by genetic, environmental, management, and interaction of these factors [7, 8]. Soil is one of the most diverse environmental factors. This diversity affects soil nutrient dynamics. Due to this diversity, site-specific fertilization is required [6,9]. Management is an important factor, especially in suboptimal environments, including the environment in dry land agro-ecosystems, tides, 
and non-swamp wetlands. Various constraints on crop production are faced in the use of dry lands, swamplands, and paddy fields.

Constraints faced on dryland and swampland include low soil $\mathrm{pH}$, low availability of nutrients, and high soil Fe content $([10,11,12,13]$. In paddy fields, the problem faced is a decrease in land productivity due to inappropriate management. Soil acidity (low $\mathrm{pH}$ ) is a limiting factor in rice [14] and maize production. The results showed that low soil $\mathrm{pH}$ had an impact on reducing maize yields by $11-37 \%$ [15], and rice yields from $14.52-28.97 \%$ [16]. Rice productivity in acid soils can be increased, among others, through the application of lime [17], and the application of Ground Magnesium Limestone (GML) in combination with a biofertilizer [13].

The potential of dry lands, swamplands, and non-swamp wetland agro-ecosystems reaches 188.038 million ha in Indonesia [1]. The types of soil scattered in these land resources include Inceptisols, Oxisols, Vertisols, and Andisols. These soil types are a potential source of production in the development of rice, maize, and soybean commodities. Viewed from the aspect of broad potential, these land types are prospective to be developed as a source of food commodity production, especially rice and maize.

Table 1. Fertilization grouping and recommendation criteria of degraded rice fields

\begin{tabular}{|c|c|c|c|c|c|}
\hline \begin{tabular}{|l} 
Level of \\
Degradation
\end{tabular} & \multirow{2}{*}{$\begin{array}{l}\mathbf{P} \\
\text { Nutrient } \\
\text { Status } \\
\text { low }\end{array}$} & \multirow{2}{*}{$\begin{array}{l}\text { K } \\
\text { Nutrient } \\
\text { Status } \\
\text { low }\end{array}$} & \multirow{2}{*}{$\begin{array}{l}\text { C } \\
\text { Content } \\
\text { low } \\
\end{array}$} & \multicolumn{2}{|c|}{$\begin{array}{c}\text { Fertilization } \\
\text { Recommendations }\end{array}$} \\
\hline \multirow{8}{*}{ Heavy } & & & & & \\
\hline & low & low & medium & SP-36 & $75-100 \mathrm{~kg} / \mathrm{ha}$ \\
\hline & 1,ow & low & high & $\mathrm{KCl}$ & $50-100 \mathrm{~kg} / \mathrm{ha}$ \\
\hline & low & low & low & $\begin{array}{l}\text { Organic } \\
\text { fertilizer }\end{array}$ & $\begin{array}{l}3 \mathrm{t} / \mathrm{ha} / \text { season } \\
\text { (continously) }\end{array}$ \\
\hline & low & high & low & Biofertilizer & $200 \mathrm{~g} / \mathrm{ha}$ (liter/ha) \\
\hline & medium & low & low & Decomposer & $5-6 \mathrm{~kg} / \mathrm{ha}$ \\
\hline & medium & medium & low & $\begin{array}{l}\text { Cultivation of } \\
\text { Land }\end{array}$ & $\begin{array}{l}\text { Plow up to } 20 \mathrm{~cm}+ \\
\text { Rotary }\end{array}$ \\
\hline & high & low & low & & \\
\hline \multirow{9}{*}{ Medium } & low & low & medium & & \\
\hline & low & medium & high & & \\
\hline & low & high & medium & SP-36 & $75-100 \mathrm{~kg} / \mathrm{ha}$ \\
\hline & medium & low & medium & $\mathrm{KCl}$ & $50-100 \mathrm{~kg} / \mathrm{ha}$ \\
\hline & medium & high & low & $\begin{array}{l}\text { Organic } \\
\text { fertilizer }\end{array}$ & $\begin{array}{l}2 \mathrm{t} / \mathrm{ha} / \text { season } \\
\text { (continously) }\end{array}$ \\
\hline & medium & high & low & Biofertilizer & $200 \mathrm{~g} / \mathrm{ha}$ (liter/ha) \\
\hline & high & low & medium & Decomposer & $5-6 \mathrm{~kg} / \mathrm{ha}$ \\
\hline & high & medium & low & $\begin{array}{l}\text { Cultivation of } \\
\text { Land }\end{array}$ & $\begin{array}{l}\text { Plow up to } 20 \mathrm{~cm}+ \\
\text { Rotary }\end{array}$ \\
\hline & high & high & low & & \\
\hline \multirow[t]{7}{*}{ Low } & low & high & high & & \\
\hline & medium & low & high & SP-36 & $75-100 \mathrm{~kg} / \mathrm{ha}$ \\
\hline & medium & medium & medium & $\mathrm{KCl}$ & $50-75 \mathrm{~kg} / \mathrm{ha}$ \\
\hline & medium & high & medium & $\begin{array}{l}\text { Organic } \\
\text { fertilizer }\end{array}$ & $\begin{array}{l}2 \mathrm{t} / \mathrm{ha} / \text { season } \\
\text { (continously) }\end{array}$ \\
\hline & high & low & high & Biofertilizer & $200 \mathrm{~g} / \mathrm{ha}$ (liter/ha) \\
\hline & high & medium & medium & Decomposer & $5-6 \mathrm{~kg} / \mathrm{ha}$ \\
\hline & & & & $\begin{array}{l}\text { Cultivation of } \\
\text { Land }\end{array}$ & Rotary \\
\hline
\end{tabular}

Source: [2] 
Researches on rice and maize on several types of soil of location specification have been carried out. This research aimed to obtain a cultivation technology package. Several reports showed that the soil characteristics at the research location were: (a) slightly acidic soil $\mathrm{pH}$, (b) very low-low-very high $\mathrm{P}_{2} \mathrm{O}_{5}$, (c) low-moderate $\mathrm{K}_{2} \mathrm{O}$, and (d) very low-low organic matter content. Based on the characeristics, these data showed that the soil in the various study sites had been degraded. The same thing was reported by researchers [18], that the indicators of degraded soil based on the International Organization for Standardization are characterized by low exchange capacity for cations, $\mathrm{P}$, organic matter, and $\mathrm{pH}$. According to researchers $[19,20,21]$, excessive application of fertilizers in intensive agricultural practices is one of the causes of soil nutrient imbalance, and soil degradation. The indicator of degraded soils (light-moderate-heavy) was a combination of P, K nutrient status and soil organic matter content [2]. The level of degradation based on the nutrient status of $\mathrm{P}, \mathrm{K}$, soil $\mathrm{C}$ content, and fertilization recommendations are shown in Table 1.

\section{Role of Cultivation Technology in Increasing Productivity of Lands and Plants}

The success of increasing food crop production is the impact of the implementation of the extensification (area expansion) and intensification (technology) program. In maize, the portion of technology plays a more dominant role in increasing production than the portion of the role of area expansion and the portion of the interaction between them.

Efforts to increase rice productivity have been carried out by the government such as through Integrated Rice Production Development program. The development of this program is carried out through the Integrated Crop Management (ICM) Approach. The rice ICM technology package consists of new high yielding varieties of location specification, certified seeds, improved/increased height of embankment, joint nurseries, optimal plant populations/legowo, fertilization of location specification, water management, integrated pest management and acceleration of the implementation of the grain process. Zaini cit. Zaini [5] mention that, of the 9 technology components, fertilization of location specification provides the largest portion of increasing grain yield and rice farmer income. The share of increased yields and the portion of increased profits through the implementation of this technology reached $24.7 \%$ and $25.5 \%$, respectively.

The role of technology effectiveness in increasing productivity on degraded lands will be increasingly needed, especially in supporting sustainable agriculture and improving farmers' welfare. In the long term, it is hoped that the implementation of effective cultivation technology on degraded lands will have an impact on improving the welfare of farmers.

Efforts to restore degraded lands can be carried out through balanced fertilizers, organic fertilizers and biofertilizers [2]. Balanced fertilization is given according to plant nutrient needs and based on nutrient availability in the soil. Fertilization recommendations based on the level of soil fertility degradation are available, especially for paddy fields (Table 1). At the field level, the effectiveness of fertilization can still be rationalized depending on the variety of varieties and climate.

\section{Research Results on RAE (Relative Agronomic Effectiveness- Based Cultivation Technology}

The effectiveness of a technology can be determined by calculating the value of Relative Agronomic Effectiveness (RAE). Variables and RAE value information from the research results of fertilization of location specification are very important to be 
disseminated. This effort has the opportunity to increase the adoption of a technology and determine the sustainability of its implementation at the farm level.

RAE value is the percentage increase in productivity on a technology being tested compared to the percentage of productivity on the use of standard/recommended technology. This value shows the level of effectiveness of a technology being tested compared to the standard technology. RAE value on the use of standard technology is $100 \%$. RAE value $>100 \%$ means the technology researched or tested is more effective than the standard technology. Chien et al. cit. Frazao et al. [22] mention that, RAE value can be calculated using the following formula:

$$
\mathrm{RAE}=\frac{\mathrm{Yt}-\mathrm{Yc}}{\mathrm{Ys}-\mathrm{Yc}} \times 100 \%
$$

Description:

$\mathrm{RAE}=$ Relative Agronomic Effectiveness

Yt $=$ Yields on technology tested $(\mathrm{t} / \mathrm{ha})$

Ys $=$ Yields on standard technology $(\mathrm{t} / \mathrm{ha})$

$\mathrm{Yc}=$ Yields on controls $(\mathrm{t} / \mathrm{ha})$

\subsection{Determination of Standard Fertilization in Agronomy Effectiveness Based Research}

The adoption of technology by farmers, among others, is influenced by personal variables, such as the strength of the farmer's character. In terms of social aspects, the adoption of sustainable technology by farmers has been slow. Li et al. [23] argued that, this was partly due to the lack of motivation of farmers. Thus the approach needed relating to the adoption of sustainable technology is an extension based on the strength of the character of farmers [24]. From an economic aspect, several indicators must be met for a technology to be adopted sustainably. The indicators consist of effeciency in resource utilization $[25,26,27]$ increase in income, and the ease of application. Technology supperiority, including the technology with socio-economic indicators as the basis, will highly determine the adoption and sustainability of its implementation by the farmers.

Treatment variables needed in the RAE based research are standard fertilization, and alternative fertilization that will be tested and will be treated as control. Technology support in determining the standard fertilizer in RAE based research is available. The specific alternative fertilization technology that will be tested is based on the dose and/or dose combination of alternative fertilizers (inorganic, organic, biofertilizer). This can be customized with farmers' existing technology and the availability of in-situ resources.

Based on the income indicator, resource utilization efficiency, and the ease of application, currently technological devices for determining standard fertilizer for upland, swampland, and paddy field are available [28]. The devices are Upland Soil Test Kit, Swampland Soil Test Kit, and Paddy Soil Test Kit. Nutrient level of land (organic P, K, C), soil $\mathrm{pH}$, and fertilization recommendation can be known through the use of these devices (Table 2, Table 3, Table 4, and Table 5). 
Table 2. Determination of standard fertilizer for rice and corn based on the Upland Soil Test Kit

\begin{tabular}{|c|c|c|c|c|c|c|c|c|c|c|}
\hline \multirow[t]{3}{*}{$\begin{array}{l}\text { Nutrient } \\
\text { Status }\end{array}$} & \multicolumn{4}{|c|}{$\begin{array}{c}\text { Dose (kg Urea/ha) } \\
\text { Dose (t organic matter/ha) }\end{array}$} & \multicolumn{2}{|c|}{$\begin{array}{c}\text { Dose } \\
\text { Non Andisol } \\
\text { (kg Urea/ha) }\end{array}$} & \multicolumn{2}{|c|}{$\begin{array}{c}\text { Dose } \\
\text { Andisol (kg } \\
\text { SP-36/ha) }\end{array}$} & \multicolumn{2}{|c|}{$\begin{array}{c}\text { Dose } \\
(\mathrm{kg} \mathrm{KCl} / \mathrm{ha})\end{array}$} \\
\hline & \multicolumn{2}{|c|}{ Rice } & \multicolumn{2}{|c|}{ Corn } & \multirow[b]{2}{*}{ Rice } & \multirow[b]{2}{*}{ Corn } & \multirow[b]{2}{*}{ Rice } & \multirow[b]{2}{*}{ Corn } & \multirow[b]{2}{*}{ Rice } & \multirow[b]{2}{*}{ Corn } \\
\hline & $\begin{array}{c}+ \text { organic } \\
\text { matter }\end{array}$ & $\begin{array}{c}\text { - organic } \\
\text { matter }\end{array}$ & $\begin{array}{l}\text { + organic } \\
\text { matter }\end{array}$ & $\begin{array}{r}- \text { organic } \\
\text { matter }\end{array}$ & & & & & & \\
\hline Low & $200+2$ & 250 & $350+2$ & 400 & 200 & 250 & 250 & 300 & 100 & 100 \\
\hline Medium & $200+1$ & 250 & $350+1$ & 400 & 150 & 175 & 175 & 200 & 75 & 75 \\
\hline High & $200+1$ & 250 & $350+1$ & 400 & 100 & 100 & 100 & 100 & 50 & 50 \\
\hline
\end{tabular}

Source: [28]

Tablel 3. Determination of standard fertilizer for rice based on the Swampland Soil Test Kit

\begin{tabular}{|c|c|c|c|c|c|c|c|c|c|}
\hline \multirow{2}{*}{$\begin{array}{l}\text { Fertilizer } \\
\text { (kg/ha) } \\
\text { Straw } \\
(2.5 \text { t/ha) }\end{array}$} & \multicolumn{3}{|c|}{$\begin{array}{c}\text { Nutrient Status } \\
\text { (N, P, and K) } \\
\text { (Swampland) }\end{array}$} & \multicolumn{3}{|c|}{$\begin{array}{c}\text { Nutrient Status } \\
\text { (N, P, and K) } \\
\text { (Shallow Swamp) }\end{array}$} & \multicolumn{3}{|c|}{$\begin{array}{c}\text { Nutrient Status } \\
\text { (N, P, and K) } \\
\text { (Peat) }\end{array}$} \\
\hline & Low & $\begin{array}{c}\text { Mediu } \\
\mathrm{m}\end{array}$ & high & Low & $\begin{array}{c}\text { Mediu } \\
\mathrm{m}\end{array}$ & High & Low & $\begin{array}{l}\text { Mediu } \\
\mathrm{m}\end{array}$ & high \\
\hline Urea & 250 & 200 & 150 & 250 & 200 & 150 & 250 & 200 & 150 \\
\hline SP-36 & 150 & 125 & 100 & 150 & 125 & 100 & 200 & 150 & 100 \\
\hline $\begin{array}{l}\mathrm{KCl} \\
+ \text { straw }\end{array}$ & 100 & 75 & 50 & 100 & 75 & 50 & 125 & 100 & 75 \\
\hline $\begin{array}{l}\mathrm{KCl}- \\
\text { straw }\end{array}$ & 125 & 100 & 75 & 125 & 100 & 75 & 150 & 125 & 100 \\
\hline
\end{tabular}

Source: [28]

Table 4. Determination of standard Urea and SP-36 fertilizers for lowland rice based on Paddy Soil Test Kit

\begin{tabular}{|c|c|c|c|c|c|c|c|}
\hline \multirow[t]{3}{*}{ Soil Texture } & \multirow{3}{*}{$\begin{array}{l}\text { Yield } \\
\text { Target } \\
\text { (t/ha) }\end{array}$} & \multicolumn{3}{|c|}{$\begin{array}{c}\text { Recommendations } \\
\text { (kg Urea/ha) }\end{array}$} & \multicolumn{3}{|c|}{$\begin{array}{c}\text { Recommendations } \\
\text { (kg SP-36/ha) }\end{array}$} \\
\hline & & \multicolumn{3}{|c|}{ N Status } & \multicolumn{3}{|c|}{ P Status } \\
\hline & & Low & Medium & High & Low & Medium & High \\
\hline \multicolumn{8}{|l|}{ Superior Rice } \\
\hline \multirow{2}{*}{$\begin{array}{l}\text { Clayey } \\
\text { (clay 20-40\%) }\end{array}$} & 5 & 250 & 200 & 200 & 100 & 75 & 50 \\
\hline & 6 & 300 & 250 & 250 & 125 & 100 & 75 \\
\hline \multirow{2}{*}{$\begin{array}{l}\text { Sandy } \\
(\text { Clay < 20\%) }\end{array}$} & 5 & 300 & 250 & 250 & 100 & 75 & 50 \\
\hline & 6 & 350 & 250 & 250 & 125 & 100 & 75 \\
\hline \multicolumn{8}{|l|}{ Hybrid Rice } \\
\hline \multirow{2}{*}{$\begin{array}{l}\text { Clayey } \\
\text { (clay 20-40\%) }\end{array}$} & 7 & 300 & 225 & 225 & 120 & 90 & 60 \\
\hline & 8 & 350 & 300 & 300 & 150 & 120 & 90 \\
\hline \multirow{2}{*}{$\begin{array}{l}\text { Sandy } \\
(\text { clay }<20 \%)\end{array}$} & 7 & 350 & 300 & 250 & 120 & 90 & 60 \\
\hline & 8 & 400 & 300 & 300 & 150 & 120 & 90 \\
\hline
\end{tabular}

Source: [28] 
Table 5. The determination of standard $\mathrm{KCl}$ fertilizer for lowland rice based on the Paddy Soil Test Kit

\begin{tabular}{|l|c|c|c|c|}
\hline \multirow{2}{*}{$\begin{array}{l}\text { Organic } \\
\text { Matter } \\
\text { (t/ha) }\end{array}$} & \multirow{2}{*}{$\begin{array}{c}\text { Yield } \\
\text { Target } \\
\text { (t//ha) }\end{array}$} & \multicolumn{3}{|c|}{$\begin{array}{l}\text { Recommendations } \\
\text { (kg KCl/ha) }\end{array}$} \\
\cline { 3 - 5 } & & \multicolumn{3}{|c|}{ K Status } \\
\cline { 3 - 5 } & & Low & Medium & High \\
\hline Superior Rice & 5 & 100 & 50 & 50 \\
\hline - Straw (0) & 6 & 125 & 75 & 75 \\
\hline + Straw (5) & 5 & 50 & 0 & 0 \\
\cline { 2 - 5 } & 6 & 75 & 0 & 0 \\
\hline Hybrid Rice & 7 & 120 & 60 & 60 \\
\hline - Straw (0) & 8 & 150 & 90 & 90 \\
\hline + Straw (5) & 7 & 60 & 10 & 10 \\
\cline { 2 - 5 } & 8 & 90 & 15 & 15 \\
\hline
\end{tabular}

Source [28]

\subsection{RAE on Single N, P, and K Inorganic Fertilization}

The problem of soil sickness phenomenon due to inappropriate fertilization management still occurs in the practice of rice and maize farming at the farmer level. This inappropriate management includes: (a) $\mathrm{N}$ is given beyond the recommended dose, (b) P is still being given even though the $\mathrm{P}$ content of the soil is high to very high (P saturated soil), and (c) $\mathrm{K}$ is given relatively the same as the recommended dose, however, most farmers have not used it because the price of $\mathrm{KCl}$ fertilizer is expensive and often rare. In such existing land conditions, the application of $\mathrm{P}$ nutrient on land that has been given $\mathrm{P}$ nutrient (fertilized with TSP/SP 36) continuously is not effective to implement. The research results showed that [29], the RAE value $<100 \%$ was obtained in the provision of $0 \mathrm{~N}(+\mathrm{PK})$ and $0 \mathrm{~K}(+$ NP) nutrients. Table 6 shows that the effective $\mathrm{N}, \mathrm{P}$, and $\mathrm{K}$ fertilization is at the combination of $0 \mathrm{P}+\mathrm{NK}$ (RAE value $>100 \%$ ).

Table 6. RAE values in several combinations of N, P, and K nutrients in rice plants

\begin{tabular}{|l|l|c|r|r|r|}
\hline Treatment & $\begin{array}{l}\text { N-P2O5-K2O } \\
\text { (kg/ha) }\end{array}$ & $\begin{array}{c}\text { Yield } \\
\text { (g/clump) }\end{array}$ & \multicolumn{1}{c|}{$\begin{array}{c}\text { A } \\
\text { (YT-YC) }\end{array}$} & $\begin{array}{c}\text { B } \\
\text { (YS-YC) }\end{array}$ & $\begin{array}{c}\text { RAE (\%) } \\
(\mathbf{A} / \mathbf{B}) \mathbf{x}(\mathbf{1 0 0})\end{array}$ \\
\hline O NPK (control) & $0-0-0$ & 41.93 & & - & -2.47 \\
\hline O N (+ PK) & $0-56.80-47.67$ & 41.12 & -0.81 & 32.66 & 107.68 \\
\hline O P (+ NK) & $222.26-0-47.67$ & 77.09 & 35.16 & 32.66 & 93.95 \\
\hline O K (+ NP) & $222.26-56.80-0$ & 72.61 & 30.68 & 32.66 & \\
\hline $\begin{array}{l}\text { NPK } \\
\text { (farmer's } \\
\text { standard) }\end{array}$ & $\begin{array}{l}222.26-56.80- \\
\text { 47.67 }\end{array}$ & 74.58 & 32.66 & 32.66 & 100.00 \\
\hline
\end{tabular}

Source: [29]

Note: RAE (Relative Agronomic Effectiveness), YT (yields of the nutrient being tested), YC (yields on control), YS (yields on standard nutrient).

The application of single N, P, and K based on farmer standards (farmer's existing conditions) can be taken into consideration because the nutrient/fertilization technology to be recommended is relatively easy to implement and will not drastically change farmers' habits. Thus these recommendations have the opportunity to be adopted by farmers. The results of this study showed that the effectiveness of fertilization was emerged only by 
slightly changing farmers' habits as follows: (a) without giving P nutrient/TSP fertilization, (b) continuing giving $\mathrm{N}$ nutrient/urea fertilization according to habits, and (c) continuing giving $\mathrm{K}$ nutrient $/ \mathrm{KCl}$ fertilization according to habits.

Table 7. Value of RAE at various combinations of N, P and K dosages in BISI 16 hybrid maize plants

\begin{tabular}{|l|r|r|r|r|}
\hline $\begin{array}{l}\text { Treatment } \\
\text { N- P2O5- K2O } \\
\text { (kg/ha) }\end{array}$ & \multicolumn{1}{l|}{$\begin{array}{l}\text { Yield } \\
\text { (t/ha) }\end{array}$} & \multicolumn{1}{c|}{$\begin{array}{c}\text { A } \\
\text { (YT-YC) }\end{array}$} & $\begin{array}{c}\text { B } \\
\text { (YS-YC) }\end{array}$ & \multicolumn{1}{c|}{$\begin{array}{c}\text { RAE }(\%) \\
(\mathbf{A} / \mathbf{B}) \mathbf{x}(\mathbf{1 0 0})\end{array}$} \\
\hline $0-0-0$ & 5.20 & - & - & - \\
\hline $225-72-90$ & 11.03 & 5.83 & 6.31 & 92.393 \\
\hline $225-72-60$ & 11.31 & 6.11 & 6.31 & 96.830 \\
\hline $225-36-60$ & 11.03 & 5.83 & 6.31 & 92.393 \\
\hline $0-72-90$ & 4.89 & -0.31 & 6.31 & -4.913 \\
\hline $0-72-60$ & 5.31 & 0.11 & 6.31 & 1.743 \\
\hline $0-36-60$ & 5.43 & 0.23 & 6.31 & 3.645 \\
\hline $225-0-90$ & 10.51 & 5.31 & 6.31 & 84.152 \\
\hline $225-36-90$ & 10.87 & 5.67 & 6.31 & 89.857 \\
\hline $225-72-0$ & 10.42 & 5.22 & 6.31 & 82.726 \\
\hline $225-36-0$ & 11.52 & 6.32 & 6.31 & 100.158 \\
\hline $230-83-111$ & & & & \\
Standard & & & & 100.000 \\
(Nutrient Manager) & 11.51 & 6.31 & 6.31 & \\
\hline
\end{tabular}

Source: [30]. Processed data

Note: RAE (Relative Agronomic Effectiveness), YT (yields of the nutrient being tested), YC (yields on control), YS (yields on standard nutrient).

Several research results on effective $\mathrm{N}, \mathrm{P}$, and $\mathrm{K}$ fertilization in maize have been found. The nutrient manager-based fertilization dosage could still be rationalized [30]. Table 7 shows that the combination of fertilization at a rate of $225 \mathrm{~kg} \mathrm{~N} / \mathrm{ha}, 36 \mathrm{~kg} \mathrm{P} 2 \mathrm{O} 5 / \mathrm{ha}$ and $0 \mathrm{~kg}$ $\mathrm{K} 2 \mathrm{O} / \mathrm{ha}$ is more effective than the standard fertilizers (RAE value $>100 \%$ ). This fertilization technology reduces giving $\mathrm{K}$ and $\mathrm{P}$ nutrients $111 \mathrm{~kg} / \mathrm{ha}$ and $47 \mathrm{~kg} / \mathrm{ha}$ respectively.

Muriate of Potash (MOP) fertilizer is a source of nutrient potassium (K) which has the potential to increase maize and soil productivity. With the right dosage, MOP is more effective than $\mathrm{KCl}$. The research results showed that $\mathrm{KCl}$ fertilizer can be substituted by MOP fertilizer [31]. The use of MOP $100 \mathrm{~kg} / \mathrm{ha}$ is more effective than $\mathrm{KCl} 100 \mathrm{~kg} / \mathrm{ha}$ (standard). Table 8 shows that with the use of MOP $100 \mathrm{~kg} / \mathrm{ha}$, the RAE value reaches $112.83 \%$. Thus, MOP fertilizer $(100 \mathrm{~kg} / \mathrm{ha})$ is more effective than $\mathrm{KCl}$ fertilizer and has the opportunity to be implemented as an alternative source of $\mathrm{K}$ fertilizer for maize.

Table 8. Value of Relative Agronomic Effectiveness (RAE) at various doses of Muriate of Potash (MOP) on maize

\begin{tabular}{|l|r|r|}
\hline Fertilizer & Dose (kg/ha) & RAE (\%) \\
\hline Control & 0 & - \\
\hline KCl standard & 100 & 100 \\
\hline Muriate of Potash (MOP) & 25 & 25.53 \\
\hline Muriate of Potash (MOP) & 50 & 63.10 \\
\hline Muriate of Potash (MOP) & 75 & 92.51 \\
\hline Muriate of Potash (MOP) & 100 & 112.83 \\
\hline Muriate of Potash (MOP) & 125 & 61.50 \\
\hline Muriate of Potash (MOP) & 150 & 68.45 \\
\hline
\end{tabular}

Source: [31], Processed data

Note: RAE (Relative Agronomic Effectiveness) 


\subsection{RAE on the Combination of Inorganic and Organic Fertilizers}

Organic matter can increase the productivity of degraded soil such as through its role in improving soil physical, chemical, and biological properties. Improvement of soil physical properties is carried out because organic fertilizers increase soil humus thereby increasing soil aggregate stability and water retention. The effects of organic fertilizers on soil chemical properties include providing macro and micro nutrients, increasing of soil cations $[32,33]$ and anions, reducing $\mathrm{P}$ uptake by soil $[22,34]$, and reducing risks of $\mathrm{N}$ losses in acid soil [35]. Fertilization effectiveness can be increased through the application of organic fertilizers, inorganic fertilizers, or a combination of both. Organic $\mathrm{N}$ can substitute chemical $\mathrm{N}$ up to $70 \%$ [36]. Application of organic fertilizers combined with inorganic $\mathrm{P}$ fertilizers in the long term can reduce the use of $P$ fertilizers [37]. Table 9 shows that [38], agronomic effectiveness can be increased through the application of $10 \mathrm{t} / \mathrm{ha}$ of organic fertilizer (chicken manure) combined with $\mathrm{N}, \mathrm{P}$, and $\mathrm{K}$ fertilizers $(300-50-50 \mathrm{~kg} / \mathrm{ha}$ ).

Table 9. Value of Relative Agronomic Effectiveness (RAE) at various dosage combinations of inorganic and organic fertilizers

\begin{tabular}{|c|c|c|c|c|c|c|}
\hline \multicolumn{2}{|c|}{ Organic Fertilizer } & \multirow{2}{*}{$\begin{array}{c}\text { Inorganic } \\
\text { Fertilizer } \\
\text { Urea-TSP- } \\
\text { KCl (kg/ha) }\end{array}$} & \multirow{2}{*}{$\begin{array}{l}\text { Rice yields } \\
\text { (g/clump) }\end{array}$} & \multirow{2}{*}{$\frac{\mathbf{A}}{(\mathbf{Y T}-\mathbf{Y C})}$} & \multirow{2}{*}{$\begin{array}{c}\text { B } \\
(\mathbf{Y S}-\mathbf{Y C})\end{array}$} & \multirow{2}{*}{$\begin{array}{c}\text { RAE (\%) } \\
(\mathrm{A} / \mathbf{B}) \times(100)\end{array}$} \\
\hline Source & $\begin{array}{r}\text { Dose } \\
\text { (t/ha) }\end{array}$ & & & & & \\
\hline Control & 0 & 0 & 18.33 & - & - & - \\
\hline $\mathrm{N}, \mathrm{P}, \mathrm{K}$ standard & 0 & $300-50-50$ & 49.17 & 30.84 & 30.84 & 100.00 \\
\hline Straw compost & 10 & $150-25-25$ & 49.00 & 30.67 & 30.84 & 99.45 \\
\hline Straw compost & 10 & $300-50-50$ & 41.77 & 23.44 & 30.84 & 76.01 \\
\hline Chicken manure & 10 & $150-25-25$ & 42.70 & 24.37 & 30.84 & 79.02 \\
\hline Chicken manure & 10 & $300-50-50$ & 55.40 & 37.07 & 30.84 & 120.20 \\
\hline Cow dung & 10 & $150-25-25$ & 38.17 & 19.84 & 30.84 & 64.33 \\
\hline Cow dung & 10 & $300-50-50$ & 37.67 & 19.34 & 30.84 & 62.71 \\
\hline Sheep dung & 10 & $150-25-25$ & 40.67 & 22.34 & 30.84 & 72.44 \\
\hline Sheep dung & 10 & $300-50-50$ & 42.30 & 23.97 & 30.84 & 77.72 \\
\hline
\end{tabular}

Source: [38]. Processed data

Note: RAE (Relative Agronomic Effectiveness), YT (yields of the nutrient being tested), YC (yields on control), YS (yields on standard nutrient).

\subsection{RAE on the Combination of Inorganic Fertilizers and Biofertilizers}

The decomposition of organic matter depends on soil biological activity. It was suggested that soil microbial diversity is a key indicator in assessing the effectiveness of improvement in various soils [39]. Decreased organic matter content and soil biological activity are characteristic factors for degraded soils. The application of inorganic fertilizers and biofertilizers increases RAE. Based on the RAE value (Table 10), the use of Pseudobaena (cyanobacteria) was more efficient with $\mathrm{N}$ around $20-30 \%$ compared to the use of standard $\mathrm{N}$ without cyanobacteria [40]. Chittora et al. [41] mention that, Cyanobacteria is a source of biofertilizers for sustainable agriculture. Biofertilizers can increase the productivity of soils through its role in fixing $\mathrm{N}$ from the air [42], mineralization $\mathrm{N}$ [43], reducing the nitrogen loss [44], increasing $\mathrm{N}$ uptake [45], increasing the availability of $\mathrm{N}$ and $\mathrm{P}$ nutrients in the soils, releasing hormones [46], promoting plant growth [47], stimulating high expression of nitrate transporter, and increasing yield [48]. 
Table 10. Value of Relative Agronomic Effectiveness (RAE) at various dosage combinations of biofertilizers and inorganic fertilizers

\begin{tabular}{|c|c|c|c|c|c|}
\hline Biofertilizer & $\begin{array}{l}\text { Inorganic } \\
\text { fertilizer } \\
\text { (N kg/ha) }\end{array}$ & $\begin{array}{c}\text { Rice } \\
\text { yields } \\
\text { (g/clump) }\end{array}$ & $\begin{array}{c}\mathbf{A} \\
(\mathrm{YT}-\mathrm{YC})\end{array}$ & $\begin{array}{c}\text { B } \\
(\mathbf{Y S}-\mathbf{Y C})\end{array}$ & $\begin{array}{c}\text { RAE (\%) } \\
(\mathbf{A} / \mathbf{B}) \times(100)\end{array}$ \\
\hline S0 & 50 & 54.13 & - & - & - \\
\hline S0 & 60 & 65.35 & 11.22 & 28.8 & 38.96 \\
\hline S0 & 70 & 76.19 & 22.06 & 28.8 & 76.60 \\
\hline S0 & 80 & 61.33 & 7.2 & 28.8 & 25.00 \\
\hline S0 & 90 & 77.86 & 23.73 & 28.8 & 82.40 \\
\hline S0 (standard) & 100 & 82.93 & 28.8 & 28.8 & 100.00 \\
\hline Nostoc & 50 & 58.47 & 4.34 & 28.8 & 15.07 \\
\hline Nostoc & 60 & 71.19 & 17.06 & 28.8 & 59.24 \\
\hline Nostoc & 70 & 60.37 & 6.24 & 28.8 & 21.67 \\
\hline Nostoc & 80 & 72.12 & 17.99 & 28.8 & 62.47 \\
\hline Nostoc & 90 & 74.99 & 20.86 & 28.8 & 72.43 \\
\hline Nostoc & 100 & 85.49 & 31.36 & 28.8 & 108.89 \\
\hline Pseudobaena & 50 & 65.68 & 11.55 & 28.8 & 40.10 \\
\hline Pseudobaena & 60 & 65.29 & 11.16 & 28.8 & 38.75 \\
\hline Pseudobaena & 70 & 83.88 & 29.75 & 28.8 & 103.30 \\
\hline Pseudobaena & 80 & 86.22 & 32.09 & 28.8 & 111.42 \\
\hline Pseudobaena & 90 & 80.17 & 26.04 & 28.8 & 90.42 \\
\hline Pseudobaena & 100 & 84.75 & 30.62 & 28.8 & 106.32 \\
\hline Nost + Pseudo & 50 & 66.19 & 12.06 & 28.8 & 41.88 \\
\hline Nost + Pseudo & 60 & 75.06 & 20.93 & 28.8 & 72.67 \\
\hline Nost + Pseudo & 70 & 74.18 & 20.05 & 28.8 & 69.62 \\
\hline Nost + Pseudo & 80 & 84.22 & 30.09 & 28.8 & 104.48 \\
\hline Nost + Pseudo & 90 & 79.72 & 25.59 & 28.8 & 88.85 \\
\hline Nost + Pseudo & 100 & 87.92 & 33.79 & 28.8 & 117.33 \\
\hline
\end{tabular}

Source: [40]. Processed data

Note: RAE (Relative Agronomic Effectiveness), YT (yields of the nutrient being tested), YC (yields on control), YS (yields on standard nutrient).

\section{Conclusion}

Fertilization based on Site Specific Nutrient Management (SSNM) using Upland Soil Test Kit, Swampland Soil Test Kit, and Paddy Soil Test Kit is one of the technology expected to increase land productivity (upland, swampland, and paddy), plant productivity (rice and maize), farmers' income and welfare, and to support sustainable agriculture.

The increase opportunity of SSNM technology adoption can be done through refocusing research that explicitly using RAE parameter as basis. By using RAE value as base $(>100 \%)$, technological package that is more effective from standard/recommendation technology can be obtained. Fertilization technologies that have been produced with RAE as basis are single NPK inorganic fertilization package, combination of single NPK inorganic and compound NPK fertilizer, combination of single inorganic NPK fertilizer, and combination of single inorganic NPK fertilizer and bio fertilizer.

The availability of technological devices to determine standard fertilizer in RAE based research and the effort to accelerate the dissemination of information regarding the research results are hoped to give opportunity for the adoption to increase and for the continuity of implementation in farmer level. 


\section{References}

1. S. Ritung, E. Suryani, D. Subardja, Sukarman, K. Nugroho, Suparto, Hikmatullah, A. Mulyani, C. Tafakresnanto, Y. Sulaeman, R.E. Subandiono, Wahyunto, Ponidi, N. Prasodjo, U. Suryana, H. Hidayat, A. Priyono, W. Supriatna. Sumber Daya Lahan Pertanian Indonesia: Luas, Penyebaran, dan Potensi Ketersediaan (2015)

2. A. Mulyani, D. Setyorini, S. Rochayati, I. Las. Prosiding Seminar Nasional Teknologi Pemupukan dan Pemulihan Lahan Terdegradasi (2013)

3. W. Jiang, X. Liu, X. Wang, Y. Yin. Agronomy. 9 (2019)

4. Y. Chen, S. Hu, Z. Guo, T. Cui, L. Zhang, C. Lu, Y. Yu, Z. Luo, H. Fu, Y. Jin. Scie. of The Total Environ. 754 [2021] Article in Press

5. Z. Zaini. Iptek Tan. Pang. 7, 1 (2012)

6. S. Sharma, K.K. Rout, C.M. Khand, R. Tripathi, M., Amarash Nayak, S. Satpathy, N.C. Banik, W. Iftikar, N. Parida, V. Kumar, A. Mishra, R.L. Castillo, T. Velasco, R.J. Buresh. Field Crops Res., 241 (2019).

7. A.A. Boling, T.P. Tuong, H. vanKeulen, B.A.M. Bouman, H. Suganda, J.H.J. Spiertz. Indonesia. Agric. Syst., 103 (2010)

8. G. Zhou, Y. Mao, Lin Xue, G. Chen, H. Lu, M. Shi, Z. Zhang, X. Huang, X. Song, D. Hao. The Crop J. 2020

9. Wartini Ng., Husnain, L. Anggria, A.F. Siregar, W. Hartatik, Y. Sulaeman, E. Jones, B. Minasny. Geod. Reg. 22 (2020)

10. Husnain, S. Rochayati, T. Sutriadi, A. Nassir, M. Sarwani. Proc. Eng. 83 (2014)

11. G. Cornelissen, Jubaedah, N. L. Nurida, S. E. Hale,V. Martinsen,L. Silvani, J. Mulder. Tot. Environ. 634 (2018)

12. M.S. Imanudin, E. Armanto. APCBEE Proced. 4 (2012)

13. Q.A Pahwar, U.A. Naher, J. Shamshuddin, M.R. Ismail. Agronomy. 10 (2020).

14. L. Huang, X. Liu, Z. Wang, Z Liang, M. Wang, M. Liu, D.L. Suarez. Agric. Water Manag.. 194 (2017)

15. C. Mutimaamba, J.M. Robert, J.E. Cairns, C. Magorokosho, T. Ndhlela, C. Mukungurutse, A. Minnaar-Onton, M. Labuschagne. Crop Scie. 60 \{2020)

16. S.A. Ferdous, M.N.H. Miah, M. Hoque, M.S. Hossain, A.K. Hasan. J. Bangladesh Agril Univ. 16,3 (2018)

17. T.S. Sukitprapanon, A. Suddhiprakarn, I. Kheoruenromne, R.J. Gilkes. Geod. Reg.17 (2019)

18. P. Sklenicka, J. Zouhara, K.J. Molnarova, J. Vlasak, B. Kottova, P. Petrzelka, M. Gebhart, A. Walmsley. Land Use Policy. 95 (2020)

19. P.M. Kopittke, N.W. Menzies, P. Wang, B.A. McKenna, E. Lombi. Envir. Intern. 132 (2019)

20. M. Atieno, L. Herrmann, H.T. Nguyen, H.T. Phan, N. K. Nguyen, P. Srean, M.M.Than, R. Zhiyong, P.Tittabutr, A. Shutsrirung, L. Bräu, D. Lesueur. J. of Envir. Manag. 275, 1 (2020)

21. B.M. Shehu, B.A. Lawan, J.M. Jibrin, A.Y. Kamarad, I.B. Mohammed, J. Rurinda, S. Zingore, P. Craufur, B. Vanlauw, A.M. Adam, R. Merckx. Field Crops Res. 241 (2019)

22. J.J. Frazão, V.M. Benites, J.V.S. Ribeiro, V.M. Pierobon, J. Lavres. 2019. Geod. 337 (2019)

23. J. Li, S. Feng, T. Luo, Z. Guan. J. of Cleaner Prod. 257 (2020) 
24. S. Bukchin, D. Kerret. Heliyon 6 (2020)

25. W.J. Burke, E. Frossard, S. Kabwe, T.S. Jayne. Food Policy 86 (2019)

26. S. Fabiani, S. Vanino, R. Napoli, A. Zajícek, R. Duffkova, E. Evangelou, P. Nino. Environ. Scie. and Policy. 114 (2020)

27. J. Lankoskia, A. Thiem. Ecol. Econ. 178 (2020)

28. Balai Penelitian Tanah. Perangkat Uji Tanah dan Pupuk (2020)

29. Yustisia. Peningkatan Nutrisi Zn Beras Melalui Rekayasa Teknologi Budidaya. Disertasi (2015)

30. M. Akil. Prosiding Seminar Nasional Serealia Meningkatkan Peran Penelitian Serealia Menuju Pertanian Bioindustri (2013)

31. Nurjaya, H. Wibowo. Prosiding Konser Karya Ilmiah Tingkat Nasional Tahun 2018. Peluang dan Tantangan Pembangunan Pertanian Berkelanjutan di Era Global dan Digital (2018)

32. R. Wang, Y. Zhang, A. Cerdà, M. Cao, Y. Zhang, J. Yin, Y. Jiang, L. Chen. Geod. 289 (2017).

33. S.S. Dhaliwal, R.K. Nares, A. Mandal, R. Singh, M.K. Dhaliwal. Envir. and Sust. Indic. 1-2 (2019)

34. D. Pogorzelski, J.F.L. Filho, P.C. Matias, W.O. Santos, L. Vergütz, L.C.A. Melo. 2020. Scie. of The Total Envir. 743 (2020).

35. Z. Zhang, Z. Shi, J. Yang, B.Hao, L. Hao, F. Diao, L. Wang, Z. Bao, W. Guo. Ecol. Indic. 120 (2021).

36. X. Dai, D. Song, W. Zhou, G. Liu, G. Liang, P. He, G. Sun, F. Yuan, Z. Liu, Y. Yao, J. Cu. Soil \& Till. Res.. 205 (2021

37. M. Qaswar, H. Jing, ' W. Ahmed, · L.Dongchu, Z. Lu, A. Cai, L. Lisheng, X, Yongmei, G. Jusheng, Z. Huimin. Soil and Till. Res. 198 (2020)

38. A. Yuniarti, M. Damayani, D.M. Nur. J. Pert. Presisi, 3, 2 (2019)

39. Y. Zhang, X. Zheng, B. Guo, J. Yu, A. Carswell, T. Misselbrook, J. Zhang, C. Müller, D. Chen, H. Ding. Soil \& Till. Res. 196 (2020)

40. Balai Penelitian Tanah. Teknologi Pengelolaan Sumber Daya Lahan Menuju Usahatani Produktif dan Berkelanjutan. Laporan Tahunan 2017 ( 2018)

41. D. Chittora, M. Meena, T. Barupal, P. Swapnil, K. Sharma. Bioch. and Biophys. Rep. $22(220)$

42. D. Sahu, I. Priyadharsani, B. Rath. CIB Tech. J. Microl. 1 (2012)

43. C.O. Asadu, I.S. Ike, C.E. Onu, S.O. Egbuna, M. Onoh I, G.O. Mbah, C.N. Eze. Biotech. Report 27 (2020

44. B. Sun, L. Gu, L. Bao, S. Zhang, Y. Wei, Z. Bai, G. Zhuang, X. Zhuang. Soil Biol. and Bioch. 148 (2020)

45. H.I. Khan. Rice Scie. 25, 6 (2018)

46. J. Poveda. Crop Protect. (Article in Press)

47. W. Zhaoxiang, L. Huihu, L. Qiaoli, Y. Changyan, Y. Faxin. Rhizosphere, 16 (2020)

48. Y. Zhong, J. Hu, Q. Xia, S. Zhang. X. Li, X. Pan, R. Zhao, R. Wang, W. Yan, Z. Shangguan, F. Hu, C. Yang, W. Wang. Soil Biol. and Biochem. 143 (2020) 